\title{
Nondestructive Testing of the Corrosive Damage of Reinforced Concrete Structures Using Ultrasonic Method
}

Ming-Te Liang

Associate Professor, Department of Harbor and River Engineering, National Taiwan Ocean Universitry, Keelung, Taiwan, R.O.C.

\section{Run Huang}

Associate Professor, Department of Harbor and River Engineering, National Taiwan Ocean Universitry, Keelung, Taiwan, R.O.C.

Chii-Ming Jiang

Graduate Snudent, Deparment of Harbor and River Engineering, National Taiwan Ocean University, Keelung, Taiwan, R.O.C.

Follow this and additional works at: https://jmstt.ntou.edu.tw/journal

Part of the Civil and Environmental Engineering Commons

\section{Recommended Citation}

Liang, Ming-Te; Huang, Run; and Jiang, Chii-Ming (1996) "Nondestructive Testing of the Corrosive Damage of Reinforced Concrete Structures Using Ultrasonic Method," Journal of Marine Science and Technology. Vol. 4: Iss. 1, Article 14.

DOI: $10.51400 / 2709-6998.2547$

Available at: https://jmstt.ntou.edu.tw/journal/vol4/iss1/14

This Research Article is brought to you for free and open access by Journal of Marine Science and Technology. It has been accepted for inclusion in Journal of Marine Science and Technology by an authorized editor of Journal of Marine Science and Technology. 


\title{
NONDESTRUCTIVE TESTING OF THE CORRO- SIVE DAMAGE OF REINFORCED CONCRETE STRUCTURES USING ULTRASONIC METHOD
}

\author{
Ming-Te Liang*, Run Huang*, and Chii-Ming Jiang**
}

Keywords: amplitude, energy decay, pulse velocity.

\section{ABSTRACT}

The purpose of this study is to determine the corrosive damage of reinforced concrete members using the ultrasonic technique. The ultrasonic tester (type ULCON 3) connected the touched vertical-beam dictator (frequency: $50 \mathrm{kHz}$, diameter $=20 \mathrm{~mm}$ ) is used to measure the velocity and scan the concrete surface for predicting the corrosive damage. When the rebars are corroded, the ultrasonic wave propagation will very due to energy decay and velocity change. Based on the ultrasonic pulse velocity and amplitude, the structural quality of reinforced concrete can be predicted. Some results obtained from this investigation are described as follows: (1) The amplitude of refective wave reduces if steel corrosion occurs in the RC structures, (2) Both the ultrasonic pulse velocity and amplitude can be used to evaluate the steel corrosion in the $\mathrm{RC}$ structures, (3) If in-site technique is developed,the life-cycle ofthe $\mathrm{RC}$ structures may be justified.

\section{INTRODUCTION}

Taiwan is surrounded by the sea.Most of the important and large civil structures are nearly the coast. The chloride ion content in the air is relatively high. The corrosion rate of reinforced concrete may be affected by the chloride diffusion so that the lifecycle of the structures is shortened. Thus, it is necessary to predict the corrosive state using nondestructive technique for quality assurance. The corrosion of reinforced concrete is very difficult to detect in the beginning. When the rust is found on the concrete surface, the structures may be severely damage. However, a reliable, accurate and fast nondestructive testing method for evaluating the internal corrosion of reinforced concrete structure is still not developed.

Paper Received May, 1995. Revised June, 1996. Accepted June, 1996. Author for Correspondence: Ming-Te Liang.

*Associate Professor, Department of Harbor and River Engineering, National Taiwan Ocean University, Keelung, Taiwan, R.O.C.

**Graduate Student, Department of Harbor and River Engineering,

National Taiwan Ocean University, Keelung, Taiwan, R.O.C.
When the reinforced concrete structures suffer from corrosive damage, one can use some techniques to detect the deterioration. These methods include (1) the electric method-measure the natural electric potential. (2) magnetic analysis - detect the phase difference between the magnetic-current and the secondary-current occurs in steel. (3) X-ray - take the $\mathrm{X}$-ray photograph for predicting the corrosive damage.

The use of the ultrasonic pulse technique for detecting integrity of concrete and steel structures is very common. Chung [1] pointed out that if ultrasonic wave propagation path is vertical to the steel, then the wave velocity in reinforced concrete should be modified. Bungey [2] showed that if the sum of steel diameter is less than $20 \mathrm{~mm}$, the influence of steel can be neglected. Burdekin et al. [3] used the ultrasonic pulse amplitude to detect the reinforced concrete beam. It was founded that the amplitude of steel after corrosion was lower than the amplitude of steel without corrosion. This study uses the ultrasonic method to diagonose the corrosive damage of reinforced concrete structures.

\section{BASIC PRINCIPLE}

The transmission velocity of ultrasonic wave propagation in matter is called sound velocity. The sound velocity related to frequency and wave length is

$$
C=f \lambda,
$$

in which $\mathrm{C}=$ sound velocity $(\mathrm{km} / \mathrm{sec}), \mathrm{f}=$ frequency $(\mathrm{MHz}), \lambda=$ wave length ( $\mathrm{mm})$.

The sound velocity in particular material approaches to a constant value. However, when ultrasonic wave transmits from A materials to B materials, partly wave is reflective to $A$ materials and partly wave is incident into $B$ materials. Let $Z_{A}$ and $Z_{B}$ are respectively the impedance of material A and $\mathrm{B}$. $p_{e}, p_{r}$, and $p_{d}$ are respectively the incident, refective 
and transmission wave pressure. Their relationship is

$$
\begin{aligned}
& \frac{p_{r}}{p_{e}}=R, \\
& \frac{p_{d}}{p_{e}}=D,
\end{aligned}
$$

in which $R$ and $D$ is respectively called reflective and transmission coefficient. Use the impedance of difference material at interface to compute

$$
\begin{aligned}
& R=\frac{Z_{2}-Z_{1}}{Z_{2}+Z_{1}}, \\
& D=\frac{2 Z_{2}}{Z_{2}+Z_{1}} .
\end{aligned}
$$

The equation of equilibrium of sound pressure is

$$
p_{r}+p_{e}=p_{d} \text { or } 1+R=D
$$

In order to detect the behavior of reinforced concrete by using the ultrasonic technique. Application of ultrasonic pulse velocity to predicting whether the steel corrosion of reinforced concrete or not is described in the following:

Chung and Law [4] considered that when ultrasonic pulse propagates in concrete, the passing time is the sum of pulse through the coarse aggregate, fine aggregate and cement paste. Let $L_{C}, L_{1}, L_{2}$ and $L_{P}$ are respectively denoted the passing length in corresponding ultrasonic pulse velocity is respectively $V_{C}, V_{1}, V_{2}$ and $V_{P}$. Hence:

$$
\begin{aligned}
& L_{C}=L_{1}+L_{2}+L_{P}, \\
& \frac{L_{C}}{V_{C}}=\frac{L_{1}}{V_{1}}+\frac{L_{2}}{V_{2}}+\frac{L_{P}}{V_{P}} .
\end{aligned}
$$

$$
\begin{aligned}
& \text { However, } \\
& L_{1}=K A_{1} L_{P}, \\
& L_{2}=K A_{2} L_{P} .
\end{aligned}
$$

in which $\mathrm{K}$ is test constant ( $\mathrm{K}=0.3$ for experience value ), $A_{1}$ is the volume ratio of coarse aggregate to cement paste, $A_{2}$ is the volume ratio of fine aggregate to cement paste. From Eqs. (7) and (8), one gets

$$
V_{p}=\frac{1}{\frac{1+K A_{1}+K A_{2}}{V_{C}}-\frac{K A_{1}}{V_{1}}-\frac{K A_{2}}{V_{2}}}
$$

When ultrasonic pulse propagates in the reinforced concrete, the wave velocity is

$$
V_{e}=\frac{L_{e}}{\frac{L_{C}}{V_{c}}+\frac{L_{s}}{V_{s}}}
$$

in which Le and Ls are respectively reinforced concrete and steel length, Vs is the wave velocity in steel.

Chung [1] pointed out that when wave path is vertical to steel, the wave velocity of reinforced concrete is

$$
V_{e}=V_{s}-10.4 \times \frac{V_{s}-V_{c}}{d},
$$

in which $\mathrm{Ve}, \mathrm{Vc}$ and $\mathrm{Vs}$ are respectively the wave velocity of reinforced concrete, concrete and steel, $d$ is the diameter of steel.

British Standard institution [5] suggested that when the ultrasonic pulse propagates vertically the steel direction, the measured velocity must be multiplied a modified coefficient according to the ratio of sum of steel diameter (Ls) to total pass length (L).

\section{EXPERIMENTAL PROGRAM}

Table 1 indicates the test sample size. Figure 1 shows the test equipments of ultrasonic pulse velocity and amplitude. For the ultrasonic pulse velocity, turn the decay control gate on the line of wave front

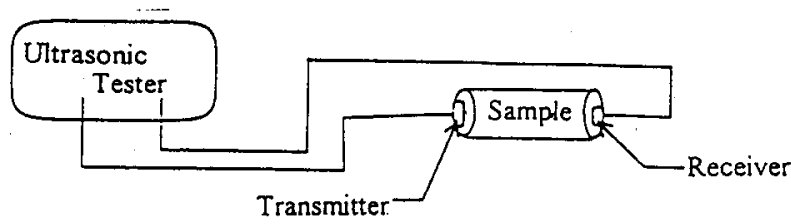

a. Ultrasonic Pulse Velocity

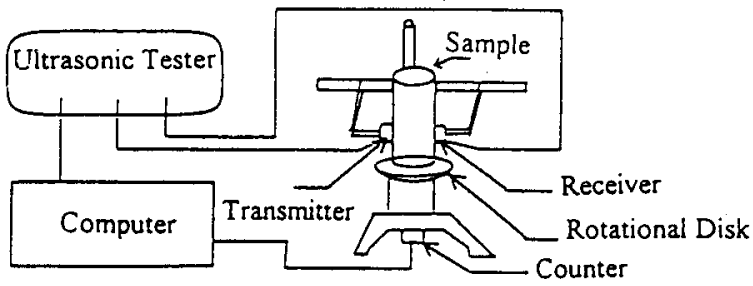

b. Ultrasonic Pulse Amolitude

Fig. 1. Test equipment.

Table 1. Test sample size

\begin{tabular}{lcc} 
Sample kind & Without corrosion & With corrosion \\
\hline Sample diameter $(\mathrm{cm})$ & $10,12,15$ & $10,12,15$ \\
Sample length $(\mathrm{cm})$ & 20 & 20 \\
Steel number $(\#)$ & $4,5,8$ & $4,5,8$ \\
\hline
\end{tabular}


and adjust the velocity button so that numerical indicator shows sample length. Finally, turn DIS to VEL from transducer to get velocity. In the case of the ultrasonic pulse amplitude, firstly place the dry column sample on the rotational disk and turn the ultrasonic tester to zero and then countclockwise it for beginning scan. The scanner will turn up $0.508 \mathrm{~cm}$ after rotational disk taking a round. The ultrasonic tester associated with C-SCAN Signal Analysis and Display (Version 4) software acquires the percent of amplitude of reflective wave. This percent can be shown on the screen with different color (see Figure 2). The amplitude graph obtained from CSCAN can be used to predict the corrosive damage of reinforced concrete cylinder.

\section{RESULTS AND ANALYSIS}

\section{Ultmsonic Pulse Velocity}

Tables 2 and 3 present the velocity of reinforced concrete with different steel diameters and cover thickness. In neglecting the influence of cover thickness, the velocity obtained from Eq. (12) is larger than the measurement velocity. However, the velocity obtained from British Standard Institution is closed to the measured velocity. Comparing with the velocity estimated from Eq. (12), the mean error of specimens with $w / c=0.5$ is higher than that of specimens with $w / c=0.6$. Hence, when ultrasonic wave propagates vertical to the steel direction, one can use ultrasonic pulse velocity to detect the steel within reinforced concrete structures provided that the steel diameter is larger than or equal to $1.27 \mathrm{~cm}$ or the cover thickness is less than or equal to $6.23 \mathrm{~cm}$.

Table 4 shows the velocity of corrosive damage of reinforced concrete structures. The velocity with corrosion is less than the velocity without corrosion. The velocity of corrosive specimen with $\mathrm{w} / \mathrm{c}=0.5$ decreases $0.05-0.09 \mathrm{~km} / \mathrm{sec}$ while ihe velocity of corrosive sample with $\mathrm{w} / \mathrm{c}=0.6$ decreases 0.14 $0.18 \mathrm{~km} / \mathrm{sec}$. Hence, one can use the ultrasonic pulse velocity to detect the corrosion of steel within reinforced concrete structures.

\section{Ultrasonic Pulse Amplitude}

Table 5 shows the reflective and transmission coefficient and decay value at interface between concrete and steel. Figures 3 - 4 show the results of ultrasonic pulse amplitude for A-team of reinforced concrete. From Figure 4 one knows that the decayed value of No. 8 without corrosive steel of reinforced concrete is ranged from $10 \%$ to $15 \%$. This decayed value is lower than the theoretical value does. The less steel diameter, the lower decayed value. Hence, the decayed value of No. 5 without corrosive steel of reinforced concrete (see Figure 4) is lower than $5 \%$. If the steel number is lower than No. 5, then the ultrasonic pulse amplitude can not detect the existence of steel in reinforced concrete structures.

Figures $5-6$ show the results of ultrasonic pulse amplitude for B-team reinforced concrete. The per-

Table 2. The ultrasonic pulse velocity of reinforced concrete with $w / c=0.6$

\begin{tabular}{|c|c|c|c|c|c|c|c|}
\hline \multirow[b]{2}{*}{$\begin{array}{l}\text { Concrete velocity } \\
(\mathrm{km} / \mathrm{sec})\end{array}$} & \multicolumn{3}{|c|}{$\begin{array}{l}\text { Use different steel under the } \\
\text { same diameter of sample }\end{array}$} & \multicolumn{3}{|c|}{$\begin{array}{l}\text { Use different diameter of } \\
\text { sample under the same \# } 8\end{array}$} & \multirow[t]{2}{*}{$\begin{array}{l}\text { Mean } \\
\text { error }\end{array}$} \\
\hline & & 4.33 & & & 4.41 & & \\
\hline Steel No. & $\# 8$ & $\# 5$ & $\# 4$ & $\# 8$ & $\# 8$ & $\# 8$ & \\
\hline $\begin{array}{l}\text { Diameter of sam- } \\
\text { ple }(\mathrm{cm})\end{array}$ & 10 & 10 & 10 & 10 & 12 & 15 & \\
\hline $\begin{array}{l}\text { Measured } \\
\text { velocity }\end{array}$ & 4.77 & 4.62 & 4.53 & 4.71 & 4.65 & 4.56 & \\
\hline $\begin{array}{l}\text { Velocity esti- } \\
\text { mated from } \\
\text { Eq. (12) }\end{array}$ & 4.61 & 4.5 & 4.47 & 4.68 & 4.63 & 4.58 & 0.068 \\
\hline $\begin{array}{l}\text { Velocity esti- } \\
\text { mated from } \\
\text { Eq. (13) }\end{array}$ & 5.13 & 4.8 & 4.57 & 5.16 & 5.16 & 5.16 & 0.357 \\
\hline $\begin{array}{l}\text { Velocity esti- } \\
\text { mated from } \\
\text { modified coefficient }\end{array}$ & 4.71 & 4.58 & 4.53 & 4.79 & 4.75 & 4.68 & 0.067 \\
\hline
\end{tabular}


Table 3. The ultrasonic pulse velocity of reinforced concrete with $w / c=0.5$

\begin{tabular}{|c|c|c|c|c|c|c|c|}
\hline \multirow[b]{2}{*}{$\begin{array}{l}\text { Concrete velocity } \\
(\mathrm{km} / \mathrm{sec})\end{array}$} & \multicolumn{3}{|c|}{$\begin{array}{l}\text { Use different steel under the } \\
\text { same diameter of sample }\end{array}$} & \multicolumn{3}{|c|}{$\begin{array}{c}\text { Use different diameter of } \\
\text { sample under the same \# } 8 \\
\text { steel }\end{array}$} & \multirow[t]{2}{*}{$\begin{array}{l}\text { Mean } \\
\text { error }\end{array}$} \\
\hline & & 4.47 & & - & 4.54 & & \\
\hline Steel No. & \# 8 & \# 5 & $\# 4$ & $\# 8$ & $\# 8$ & $\# 8$ & \\
\hline $\begin{array}{c}\text { Diameter of sam- } \\
\text { ple }(\mathrm{cm})\end{array}$ & 10 & 10 & 10 & 10 & 12 & 15 & \\
\hline $\begin{array}{l}\text { Measured } \\
\text { velocity }\end{array}$ & 4.85 & 4.75 & 4.65 & 4.81 & 4.78 & 4.7 & \\
\hline $\begin{array}{l}\text { Velocity esti- } \\
\text { mated from } \\
\text { Eq. (12) }\end{array}$ & 4.73 & 4.63 & 4.59 & 4.78 & 4.74 & 4.7 & 0.062 \\
\hline $\begin{array}{l}\text { Velocity esti- } \\
\text { mated from } \\
\text { Eq. (13) }\end{array}$ & 5.18 & 4.89 & 4.69 & 5.21 & 5.21 & 5.21 & 0.308 \\
\hline $\begin{array}{l}\text { Velocity esti- } \\
\text { mated from } \\
\text { modified coefficient }\end{array}$ & 4.86 & 4.73 & 4.68 & 4.93 & 4.89 & 4.82 & 0.068 \\
\hline
\end{tabular}

Table 4. The velocity of corrosive damage of reinforced concrete structures A team: Sample diameter 10 cm with different steel No.

\begin{tabular}{|c|c|c|c|c|c|c|}
\hline $\mathrm{W} / \mathrm{C}$ & & 0.5 & & & & 0.6 \\
\hline Steel No. & \# 8 & $\# 5$ & $\# 4$ & \# 8 & $\# 5$ & $\# 4$ \\
\hline Without corrosion & 4.85 & 4.75 & 4.65 & 4.77 & 4.62 & 4.53 \\
\hline Saw type corrosion & 4.85 & 4.74 & 4.66 & 4.77 & 4.7 & 4.53 \\
\hline Natural corrosion & & 4.74 & & & 4.6 & \\
\hline
\end{tabular}

B team: use steel No. 8 with different sample diameter

\begin{tabular}{ccccccc}
\hline Sample diameter & 10 & 12 & 15 & 10 & 12 & 15 \\
Without corrosion & 4.81 & 4.78 & 4.7 & 4.71 & 4.65 & 4.56 \\
With corrosion by us- & 4.72 & 4.73 & 4.63 & 4.57 & 4.51 & 4.38 \\
ing electric potential & & & & & & \\
\hline
\end{tabular}

\section{9.}

Fig. 2. The relationship of decayed amplitude of reflective wave with color.

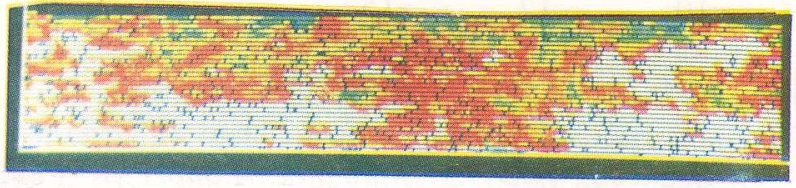

Fig. 3. Amplitude diagram of No. 8 without steel corrosion in the RC structures.

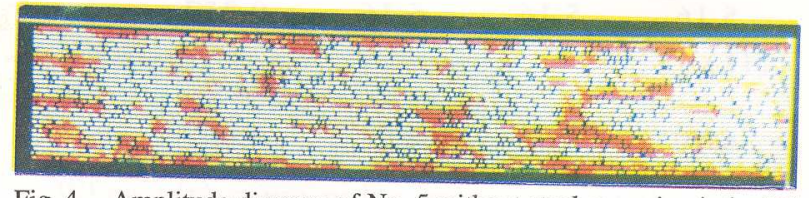

Fig. 4. Amplitude diagram of No. 5 without steel corrosion inthe RC structures.

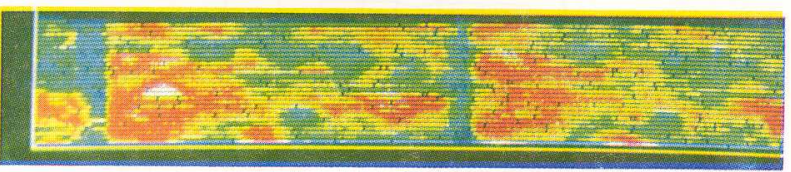

Fig. 5. Amplitude diagram without steel corrosion in the RC structures $($ diameter $=12 \mathrm{~cm}, \mathrm{~W} / \mathrm{C}=0.6,62 \mathrm{~dB})$.

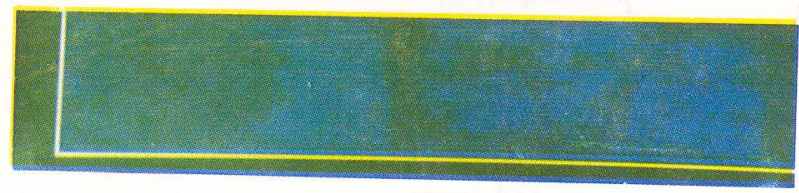

Fig. 6. Amplitude diagram of steel corrosion in the $\mathrm{RC}$ structures with electric potential (diameter $=12 \mathrm{~cm}, \mathrm{~W} / \mathrm{C}=0.6,62 \mathrm{~dB}$ ). 
Table 5. The reflective and transmission coefficient at interface between concrete and steel

\begin{tabular}{ccccccc}
\multirow{2}{*}{ Team } & W/C & \multicolumn{2}{c}{ Concrete-Steel } & \multicolumn{2}{c}{ Steel-Concrete } & Decay value (\%) \\
\cline { 3 - 6 } & & $\mathrm{R}$ & $\mathrm{D}$ & $\mathrm{R}$ & $\mathrm{D}$ & \\
\hline \multirow{2}{*}{$\mathrm{A}$} & 0.5 & 0.602 & 1.602 & -0.602 & 0.398 & 36.24 \\
& 0.6 & 0.616 & 1.616 & -0.616 & 0.384 & 37.95 \\
\multirow{2}{*}{ B } & 0.5 & 0.592 & 1.592 & -0.592 & 0.408 & 35.05 \\
& 0.6 & 0.062 & 1.602 & -0.602 & 0.398 & 36.24 \\
\hline
\end{tabular}

Table 6. Percent $(\%)$ of decayed amplitude of $B$ team reinforcent concrete

\begin{tabular}{ccccccc}
\hline W/C & \multicolumn{3}{c}{0.5} & & \multicolumn{3}{c}{0.6} \\
\hline $\begin{array}{c}\text { Sample diameter (cm) } \\
\text { Without plus }\end{array}$ & 10 & 12 & 15 & 10 & 12 & 15 \\
$\begin{array}{c}\text { electric potential } \\
\text { With plus } \\
\text { electric potential }\end{array}$ & 50 & 70 & 55 & 80 & 70 & 60 \\
& & 55 & 20 & 55 & 35 & 15 \\
\hline
\end{tabular}

cent of amplitude after decay is indicated in Table 6. Table 6 denotes that the sample diameter increases, the decayed value increases. Hence, one can use the ultrasonic pulse amplitude to predict the steel corrosion.

\section{CONCLUSIONS}

Based on ultrasonic pulse velocity and amplitude, the steel in reinforced concrete structures can be detected. Using equation (12) and Table 4, the measured pulse velocity of reinforced concrete structures is reliable. For measuring the corrosive steel in reinforced concrete structures, the corrosive steel modeled by the saw-shape reinforced concrete can not be detected whether steel corrosion or not by the method of ultrasonic pulse velocity. However, using ultrasonic pulse amplitude to measure the decayed value is larger $(10 \%-15 \%)$ than the amplitude without steel corrosion does. After the steel corrodes, the crack is formed at the interface between steel and concrete. Therefore, the pulse velocity tends to decreasing and the decayed value of amplitude of reflective wave increases. Hence, both ultrasonic pulse velocity and amplitude can be used to measure the steel corrosion of reinforced concrete structures.

\section{REFERENCES}

1. Chung, H.W., "An Appraisal of the Ultrasonic Pulse Technique for Detectng Voids in Concrete," Concrete, Vol. 12, No. 11, London, Nov. pp. 25-28 (1978).

2. Bungey, J.H., "Effects of Steel on Ultrasonic Measurements for Concrete Members," LABSE, Venice Symposium. Final Report. pp. 93-100 (1983).

3. Burdekin, F.M., John, D.G., Payne, P.A, Smith, T.A, and Gaydecki, P.A "Nondestructive Methods for Field Inspection of Embedded or Encased High Strength Steel Rods and Cables,"NCHRP Project 1030(3). Final Report, Phase 2, May (1991).

4. Chung, H.W and Law, K.S. (1983), "Diagnosing in Situ Concrete by Ultrasonic Pulse Technique," Concrete International, October, pp. 42-49 (1983).

5. British Standard Institution "Recommendations for Non-destructive Methods of Test for Concrete - Measurement of the Velocity of Ultrasonic Pulse in Concrete," BS 4408, part 5, London, Feb (1974).

\section{超音波檢測鋼筋混凝土結構物之腐 蝕損傷}

梁明德黄然江殿明

國立台瀿海洋大拿河海工程系所

摘 要

本文的主要目的是採用超音波方法決定銅筋 混凝土構件之腐蝕損賃, 使用ULCON3型探测儀及 探頭（頻率: $500 \mathrm{kHz}$, 直徑: $20 \mathrm{~mm}$ ) 量測速度及 摛瞄混凝土表面預测腐蝕損偣, 當銅筇腐蝕時, 超 音波傅遞速度將因能量的消減而引致波傅速度改 系, 利用超音波之脈波波速及振幅即可評估铜等混 凝土之結椦品質, 由本研究可得到下列結論：(1)若 銅筋混凝土結棈物之銅筋腐蝕, 則反射波之振幅將 降低，(2)超音波之脈波波速及振幅可评估铜筋混凝 土結構物之銅筋腐皓程度，(3)發展超音波非破壤性 检湘技衍, 可評估現場銅筋混凝土結構物之生命週 期。 